Aletria, Belo Horizonte, v. 28, n. 4, p. 11-29, 2018

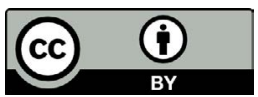

\title{
In Poetic Memory of Zumbi's Palmares and Abdias do Nascimento's Quilombismo. In Homage to Abdias do Nascimento (1914-2011)
}

\author{
Em memória poética dos Palmares de Zumbi \\ e do Quilombismo de Abdias do Nasscimento.
} Em homenagem a Abdias do Nascimento (1914-2011)

\author{
Dawn Duke \\ University of Tennessee, Knoxville, Tennessee / Estados Unidos \\ dduke1@utk.edu
}

\begin{abstract}
Modern urban formations of the Arts (such as the literary published phenomenon known as Cadernos negros) and activism have roots in the ZumbiPalmares legacy. Quilombismo, created by Abdias do Nascimento, serves to explain this experience. A contemporary philosophy of identity and nationhood, Quilombismo mirrors Negritude, embracing transformations that erode injustice and inequality. It emerged as a product of Nascimento's commitment to politics, the Black Movement, literature, and theater. He envisioned his art, speeches, essays, and activism as part of the global anti-racist democratization; his writings reveal influences from Pan-Africanism and a deep commitment to Afro-Brazil. The elevation of quilombo from maroonage and black rural communities to the level of philosophy has provided impetus to date, as literature and activism maintain momentum in an era of diversity. Moving beyond fleeing black bodies in search of Palmares, an image frozen in time, this thinker has provoked dynamic perceptions of cultural affirmation, ensuring the survival of values associated with Zumbi's Palmares.
\end{abstract}

Keywords: Quilombismo; Zumbi; Palmares; Adbias do Nascimento; Cadernos negros.

Resumo: Algumas formações urbanas modernas no campo das Artes (tais como o fenômeno de publicação literária conhecido como Cadernos negros) e do ativismo têm como fonte o legado de Zumbi dos Palmares. O Quilombismo, criado por 
Abdias do Nascimento, tem a capacidade de explicar tal relação. Como uma filosofia contemporânea de identidade e nacionalidade, o Quilombismo espelha a Negritude, engendrando transformações que desintegram injustiças e desigualdades. O conceito emerge como resultado do compromisso de Nascimento com a política, o Movimento Negro, a literatura e o teatro. Vislumbrando sua arte, seus discursos, seus ensaios e seu ativismo como parte de um movimento global de democratização antirracista, Abdias do Nascimento produziu textos que revelam influências do Pan-Africanismo, além de uma dedicação profunda ao Brasil afrodescendente. A elevação da ideia de quilombo como prática de resistência ou como comunidade rural a um patamar filosófico gerou um ímpeto que se mantém na atualidade, à medida que a literatura e o ativismo mantêm seu elã em uma era marcada pela diversidade. Indo além de corpos negros em fuga na busca por Palmares, uma imagem congelada no tempo, o pensamento de Abdias do Nascimento tem provocado percepções dinâmicas de afirmação cultural, assegurando a sobrevivência de valores associados aos Palmares de Zumbi.

Palavras-chave: Quilombismo; Zumbi; Palmares; Adbias do Nascimento; Cadernos negros.

This study examines the contemporary relevance of Afro-Brazilian poetry that pays homage to Zumbi and the nation of Palmares, within the broader cultural context of an aesthetic of Negritude anchored in Abdias do Nascimento's theory of Quilombismo. Modern urban formations of the Quilombola Movement rooted in the legacy of ancestral land rights and indemnity of rural communities, along with representations of the Zumbi-Palmares legacy in the Arts, complete the frames of reference that inspire poetic writings and the world of which such writings are an integral part. The argument is that such writing is today riding on the wave of progressive democratization in Brazil, compounded by an apparent prosperity, in large part due to the policies of Affirmative Action and the 10.639 Law sanctioned in 2003 that mandates the teaching of African and Afro-Brazilian history and culture in schools. ${ }^{1}$ To what extent does this democratic valuing translate into concrete expansion of interest in writing of consciousness by Afro-Brazilian writers? Poets Jamu Minka, Esmeralda Ribeiro, Oubi Inaê Kibuko, Lande Onawale, Eduardo de Oliveira, Abelardo Rodrigues, Cuti (Luiz Silva), Miriam Alves, among

\footnotetext{
${ }^{1}$ MARTINS et al. Paving Paradise: The Road from "Racial Democracy" to Affirmative Action in Brazil; SANTANA. Breve reflexão sobre a Lei 10.639.
} 
others, have for decades produced writings about maroonage as symbolic and political stance, often using linguistic, ethnic, spiritual, mythical, and historical elements that represent Africa in Brazil. Their literary activism can arguably be seen as coinciding with this new environment of tolerance and enthusiasm that is mainstreaming the Afro-Brazilian literary aesthetic even as thematically their underlying literature-based campaign for cultural and political transformation inspired in the Palmares legacy continues to go relatively unheard.

Leite and Cuti discuss such valuing within the broader experience of the rise and development of black political activism and the black press. They argue that contemporary homage to Zumbi and the Quilombo of Palmares confirms the centuries-old legacy that inspired the labors of activists and writers intent on recuperating this lesser taught version of national history, especially during the first decades of the twentieth century: "The first movement there was in terms of freedom in Brazil was the Quilombo of Palmares movement". ${ }^{2}$

The construction of Quilombismo as a contemporary philosophy of identity and nationhood mirrors the establishment of Negritude in the way poetics (the Arts) and politics (the ideological struggle) combine their strengths to force society toward those positive cultural transformations that erode injustice and inequality. As occurred with the emergence and consolidation of Pan-Africanism associated with W. E. B. Du Bois, Jomo Kenyatta, and Kwame Nkrumah, as well as Negritude associated with the politics and poetics of Léopold Sédar Senghor, Aimé Césaire, and Leon Damas, it is clear that Quilombismo emerged in the post-World War II era, a product of the life and work of Abdias do Nascimento (1914-2011) in politics, the Black Movement, literature, and theatre. The presentation of quilombo as the ideal state of being is at the center of what was for Nascimento a vital and intense struggle. ${ }^{3}$

Ojo-Ade ${ }^{4}$ confirms Quilombismo as a discursive force is Nascimento's contribution to global postulations of Pan-Africanism,

\footnotetext{
2 "O primeiro movimento que houve em termos de liberdade no Brasil foi o movimento do Quilombo dos Palmares" (LEITE; CUTI. ...E disse o velho militante José Correia Leita, p. 68, my translation).

${ }^{3}$ NASCIMENTO. Brazil: Mixture or Massacre? Essays in the Genocide of a Black People.
}

${ }^{4}$ OJO-ADE. Being Black, Being Human: More Essays on Black Culture. 
Negritude, and the local Black Movement in Brazil. ${ }^{5}$ The elevation of quilombo from its original meaning as maroonage and its contemporary association with the remaining black rural communities, to the level of philosophical thought that drives a contemporary state of being has provided tremendous leverage for all black activism as it seeks to maintain momentum, a challenge today in the face of tremendous diversity; such a cause seems destined to be engulfed by multiple heterogeneous positions and their equally legitimate causes and demands. ${ }^{6}$ Quilombo today retains its vitality as "an idea-force, a discursive territory" ${ }^{7}$ Ratts acknowledges the strategic existence of a permanent movement based on the principles of demand, endeavor, and restoration of freedom, one whose design accommodates contemporary notions of diversity, differentiation, thereby guaranteeing its modernization and continued relevance. Even as poetry and history have at times cultivated a vision of Palmares frozen in time, Nascimento's enterprise, rooted in cultural preservation, has invited dynamic perceptions of issues related to AfroBrazilian affirmation, thereby ensuring the continuation of the Africanbased values ingrained in the very structure of the Republic of Palmares that flourished under Zumbi. ${ }^{8}$

Afro-Brazilian literary and collective memory is protective of this historically-based imagery even as debates continue among black intellectuals and poets on representations of identity, political agendas, and contemporary aesthetic depictions. The strategy that has ensured the perpetuation of Quilombismo has been Nascimento's clear vision that this is a collective and not an individual struggle. He has always emphasized the role of intellectuals in proposing alternative routes and interpretations of black experiences in the diaspora, in relation to global Pan-Africanism, the movement that inspired him deeply. Zumbi has marched forward more than three centuries to join twentieth-century freedom fighters and martyrs as part of a universal plan of heroism and

\footnotetext{
${ }^{5}$ NASCIMENTO. O Quilombismo.

${ }^{6}$ NASCIMENTO. African Culture in Brazilian Art; NASCIMENTO. O Quilombismo; NASCIMENTO; NASCIMENTO. Africans in Brazil: A Pan-African Perspective.

7 "Uma idéia-força, um território discursivo" (RATTS. A voz que vem do interior: intelectualidade negra e quilombo, p. 90, my translation).

${ }^{8}$ NASCIMENTO. Brazil: Mixture or Massacre? Essays in the Genocide of a Black People; FUNARI. Conflict and the Interpretation of Palmares, a Brazilian Run-Away Polity.
} 
hope, essential building blocks for the first independent nations in Africa and their descendants across the globe. ${ }^{9}$

The structural similarities between Pan-Africanism and Quilombismo confirm this thinker's original plan of creating connections with global identities while contemplating an original theory of AfroBrazilian consciousness. There are various stages to his envisioning of the quilombo in history, in its original state, and quilombo hoje (quilombo today); these stages come alive as strategies in social arenas and as aesthetic points of reference visible in the Cadernos negros series. Themes in poetry include: creativity and unity; empowering language; acts of resistance and sabotage; from plantation enslavement to urban marginalization; moving against Abolition; imagining the heroic black man; and evocations of those who are absent, silenced, and imprisoned. Such themes are reminiscent of Nascimento's literary direction; in his own words, "it is in the scratches and songs that my art is born" ${ }^{10}$ Nascimento has always promoted a philosophy of difference and the nature of the need he was addressing determined the kind of theorizing he cultivated for it was never purely abstract, never purely aesthetic. This aim at relevance is very visible in his theatrical works Sortilégio (1959) and Sortilégio II (1979), where the art of symbolism and deep knowledge of Afro-Brazilian ritualism mark such dramatic performance. Sortilégio II was written in the 1970s after the author spent time at the Obafemi Awolowo University in Ile Ife, Nigeria. ${ }^{11}$ Both plays focus on the kingdom of Palmares and the iconic figure of Zumbi whose heroism places emphasis on the struggle for freedom, human dignity, and the legacy of peoples of African descent.

The act of theorizing the quilombo was the result of an accumulation of his life's experiences. Writing on the topic of exile, Nascimento defined himself as an alienated subject, consequently a political agent for his country at home and abroad. He claims "nasci exilado" (I was born exiled) ${ }^{12}$ in reference to historical cultural separation from Africa, oppression, and discrimination in Brazil, a permanent condition that determined his

\footnotetext{
${ }^{9}$ NASCIMENTO; NASCIMENTO. Africans in Brazil: A Pan-African Perspective. 10 "É nos pontos riscados e cantados que nasce minha arte." (NASCIMENTO. Abdias do Nascimento, p. 23, my translation).

${ }^{11}$ NASCIMENTO. A questão de gênero na peça Sortilégio (Mistério Negro) de Abdias Nascimento.

${ }^{12}$ NASCIMENTO. Abdias do Nascimento, p. 25.
} 
life struggles and his conscious commitment. This trajectory laid the roots for the development of his spirit and discourse on Quilombismo. Quilombismo is his life's work, experiences, and contribution to the cause. It bears the marks of his posture of non-conformism and his creativity. Contemplate his participation in the Frente Negra Brasileira (FNB, Black Brazilian Front) in the 1930s, his involvement in the development of black presses and newspapers, his founding and political lobbying on behalf of the Teatro Experimental do Negro (Negro Experimental Theatre) in the 1940s and 1950s, and his promotion of black congresses and caucuses throughout his life..$^{13}$ Consider also that he was the black intellectual who dared to incorporate into his writings terms like apartheid, genocide, and lynching to describe the Afro-Brazilian condition and very clearly states the aesthetic and artistic implications of cultural rejection. He was the warrior who intellectualized the struggle through symbolic reactivation of the old liberation war of Palmares. ${ }^{14}$ His argumentation revealed fundamental flaws in the contemporary construction of Brazilian nationhood and its deeper failure in relation to its people. ${ }^{15}$ This spirit of criticism finds duplication in the poetic tones and thematic interests of the Cadernos negros writers.

Nascimento reveals in his career and his writings a natural continuum as a citizen, professional politician, activist, and cultivator of the Arts, especially theater. ${ }^{16}$ His speeches and texts project what he saw as the black world divided, the result of separatist hierarchical constructions implemented by European expansion into Brazil. His paradigm of Quilombismo totally re-positions Brazil away from the configuration of passive colonized receptor and allegorically uses Palmares to imply a legacy of hidden and untold glory and battle, while claiming that the country's ethno-cultural identity emerges from this original city's drive, vigor, and combative spirit under the inspirational legacy of Zumbi. His speeches place quilombo and the success of Palmares at the very center

\footnotetext{
${ }^{13}$ NASCIMENTO. Abdias do Nascimento, p. 25.

${ }^{14}$ NASCIMENTO. Abdias do Nascimento; NASCIMENTO. Brazil: Mixture or Massacre? Essays in the Genocide of a Black People.

${ }^{15}$ NASCIMENTO. Brazil: Mixture or Massacre? Essays in the Genocide of a Black People.

${ }^{16}$ LARKIN NASCIMENTO. “A questão de gênero na peça Sortilégio (Mistério Negro) de Abdias Nascimento".
} 
of his political agenda as it relates to the black struggle and his project of historical re-writing of his people's role and his nation's identity. He defends the cause, ever faithful to the original premise of aggressive struggle as seen in his employment of notions such as Brazilian apartheid, the genocide of the black Brazilian, and holocaust in a space that continues to define itself in terms of democracy, harmony and fusion. ${ }^{17}$

The Cadernos negros poets in this study align their creativity with Quilombismo and do not necessarily coincide with other national literary productions about liberation struggles during Portuguese rule. Cadernos negros poets Márcio Barbosa and Oubi Inaê Kibuko have expressed concern about the limiting stereotypical portrayals of Zumbi in works like João Felício dos Santos's Ganga-Zumba (1962)..$^{18}$ Their literature experiments with history and runs parallel to the canonical literary sphere, left free to abandon itself to the vast, infinite wealth of elements that could be used to describe this experience. The Afro-Brazilian religion Candomblé, traditions, rhythm, historical events and personages, myths, Africa, a whole range of community values, and language form the basis of the rather flexible and exploratory nature of this writing. Alongside such literary freedom, there is a definite grounding in reality reminiscent of approaches found in important African works during the 1970s and 1980 s. Poetry, the most popular genre, synchronizes with social reality and human behavior; verses are both historical and creative, for they legitimize their place in the social sphere by collaborating with the process of historical re-writing of the black experience in Brazil even as they make use of techniques such as exaggeration and timelessness that immortalize the Zumbi figure.

Poetry promotes glory where before there was disregard. Cuti comments on how literature is in alliance with the black subject, "o ser negro," (the black human being) as a means of counteracting notions of harmonious cultural hegemony. ${ }^{19}$ It creates discomfort, questioning, conflict, even disorientation because this black subject is very specific,

${ }^{17}$ NASCIMENTO. Sortilégio: mistério negro; NASCIMENTO. O Quilombismo; NASCIMENTO. Brazil: Mixture or Massacre? Essays in the Genocide of a Black People; OJO-ADE. Black Brazil: African Notes on a New Negritude.

${ }^{18}$ BARBOSA. Márcio Barbosa, p. 12; KIBUKO. Reflexão sobre literatura negra na realidade política brasileira, p. 125-140.

${ }^{19}$ CUTI. O leitor e o texto afro-brasileiro, p. 28. 
meaning that the majority of readers may no longer identify themselves with the characters or visualize this literary space as their own. The very nature of this poetic rewriting challenges existing sensations of comfort and tranquility, replacing these with feelings of anguish; poetry has become profound aesthetic disturbance, of what it feels like, to use Cuti's words, "in a black person's skin". ${ }^{20}$

Zumbi appears as the flame around which the Cadernos negros poets gather. These poems allow him to assume god-like proportions within their literary sphere in order to augment his contemporary value and make this a very useful tool in those broad ideological campaigns such as the struggle against racism and inequality. Barbosa's "A morte" elevates Zumbi from the deep past to align him with twentieth century freedom fighters: Lumumba, Agostinho Neto, Zumbi dos Palmares, "today [...] I follow Zumbi, Agostinho Neto, Luther King, Mandela [...] immortal warriors of my people". ${ }^{21}$

Limeira's "Zumbi"22 counteracts lack of knowledge about this iconic freedom fighter by way of verses that evoke the epic events within slavery. Afro-Brazilian versions of those events survive through history-telling, storytelling, transmission by word of mouth, from generation to generation. Assumpção's "Linhagem" sustains this idea of greatness through the affirmation of the persona's prestigious lineage: "I am a descendant of Zumbi," a proud declaration connected to a tradition of bravery, strength, and revolt: "I carry quilombos and fierce voices within me". ${ }^{23}$

Zumbi is authentic as a subject who experienced the Middle Passage. He thrives as the medium between Africa and Brazil and is the people's memory to their lives on the old continent. Minka's "Dos Palmares" 24 reconstructs Zumbi's trajectory from Africa to enslavement to heroism. He sits among personages deserving of recognition for their contribution to the legacy. Minka connects with Teodoro, whose poem, "Queria ser um deus," is a dedication to Oswaldo de Camargo,

\footnotetext{
20 "Na pele de um negro," (CUTI. O leitor e o texto afro-brasileiro, p. 28, my translation). 21 "hoje [...] sigo Zumbi, Agostinho Neto, Luther King, Mandela [...] imortais guerreiros do meu povo" (BARBOSA. A morte, p. 56, my translation).

${ }^{22}$ LIMEIRA. Zumbi, p. 107.

23 "Sou descendente de Zumbi", "Eu trago quilombos e vozes bravias dentro de mim." (ASSUMPÇÃO. Protesto: poemas, p. 93, my translation).

${ }^{24}$ MINKA. Dos Palmares, p. 85.
} 
the oldest surviving poet, patron of the Afro-Brazilian literary legacy, and the first to propose and publish a literary history of black writing in Brazil. ${ }^{25}$ Teodoro's narrator seeks a solution and encounters in Zumbi's experiences the wisdom and knowledge to overcome the odds and achieve dignity.

Zumbi's ability to live on arises from his elevation from history into the spiritual realm. Such transcendence appears in aesthetic representations that contemplate him as an ancestral figure or deity. Palmares and Zumbi will continue to guide the struggle as sources of eternal reverence and remembering. Limeira's poem "Zumbi" makes reference to his deification and wisdom that will guide his people; he manifests as an eternal spirit appearing at ceremonial rituals. The narrator is consumed by the hero's spirit, a process of strengthening and purpose. "My teeth glitter in the dark night / Sharpened with Ogun's sword. ${ }^{26}$ This supernatural force will allow him to fight and succeed with fervent resolve and determination. The influence and power of the spiritual realm over material life and actions drives the action in this poem, connects the narrator with Yoruba-originated deities like Ogun, and makes manifest the invigorating nature of Candomblé rituals and guiding principles. The narrator pays homage to this glorious past and confirms dependency on this supernatural connection to guarantee future success.

The process of idealizing Palmares as original home, liberation, and a refuge from the plantation remains the single most important configuration that initiates the process of sustaining the legacy of the quilombo as symbolic of African resistance and nationhood in colonial Brazil. While the invigorating image of a militarized community under siege, driven forward by a series of inspirational victories, influences the epic spirit found in many poetic writings, there are other visions of what it must have been like that serve to evoke past and current notions of its value. The idea of an idyllic sanctuary in the midst of wonderful green expanse must have kept up hope of salvation. Jônatas Conceição's poem "No Nordeste existem Palmares" captures this aspect of Palmares as paradise. The narrator imagines a connection between palm trees palmeiras, and "Palmares." The actual historical site in the northeastern

\footnotetext{
${ }^{25}$ TEODORO. Queria ser um deus, p. 31; CAMARGO, O negro escrito. 26 "Meus dentes brilham na noite escura / Afiados como o agadá de Ogum." (LIMEIRA. Zumbi, p. 107, my translation).
} 
region of Brazil gains a timelessness by way of a nostalgic romanticizing of this tropical, tranquil location. "Palm trees were abundant in the old quilombo [...] Palm trees are symbols of peace and tranquility." 27 A vision of paradise in protective seclusion emerges in verses that mirror the spirit of loving nationalism reminiscent of Gonçalves Dias' "Canção do exílio" whose verses, "My land has palm trees where the sabiá bird sings" 28 are at the heart of Brazilian Romanticism and emblematic of the sentimental nationalism that marked this literary genre. At the same time, in sentiment and meaning there is a chasm of possibilities between the two poems. Conceição's poetic alliteration and recognition of the similarities and differences between the two words creates a relationship of movement back and forth between palmeiras and Palmares. The verses engage the possibility of using palm trees to re-connect Brazil and Africa as identical, as a shared identity, while proposing Palmares and the many other quilombo settlements as reminiscent of the original African spaces from which they had been taken. The poetic intention seems to be rerouting cultural understanding away from the original Romantic vision of tropical nationalistic sentiment toward a vision of Africa as origin and loss, and Palmares as Africa in Brazil.

Esmeralda Ribeiro's “África-Brasil,” Adão Ventura’s “Eu, pássaro-preto," and Aberlardo Rodrigues" "À procura de Palmares" commit to the ideal of psychological liberation. "Eu, pássaro-preto" simulates that intense desire to be free like a black bird in flight. Symbolic transference from enslaved body to bird relates to freedom as something taken, not given, while such initiative implies a spirited personality that will defend this new state of being gained at all cost: "I, / black-bird, / scar / burns from the hot iron, / I protect my escaped slave body / and / I stand guarding / the gate of the quilombos." ${ }^{29}$ Metamorphic transformation and flight remit to escape home, recovery of lost origins family, community, and even death by suicide. Symbolically, by way of verse, escape from difficulties and tragedy is the first step toward transformation and hope.

\footnotetext{
27 “As palmeiras abundavam no antigo quilombo [...] Palmeiras são símbolos de paz e sossego." (CONCEIÇÃO, No Nordeste existem Palmares, p. 25, my translation). 28 "Minha terra tem palmeiras onde canta o sabiá" (DIAS. Gonçalves Dias: Poesia completa e prosa escolhida, p. 103, my translation).

29 “eu, / pássaro-preto, / cicatrizo / queimaduras de ferro em brasa, / fecho corpo de escravo fugido/ e / monto guarda / na porta dos quilombos." (VENTURA. A cor da pele, p. 29, my translation).
} 
Literary discourse takes a political stand with respect to the apparent emptiness behind the act of manumission. Poetic refusal to celebrate May $13^{\text {th }}$ and corresponding literary homage to November $20^{\text {th }}$ synchronize with the argument coming from black poets that the postslavery challenges facing Afro-descendants begs the question whether slavery really ended. ${ }^{30}$ The act of royal benevolence immortalized in the image of a young Portuguese princess, pen in hand, has become the most important act associated with the centuries-old anti-slavery and abolitionist struggle. As a law that was imposed from the top down in a State-mandated act that in the end may have really been the result of industrial and financial self-interests, it becomes problematic for the way it retains the status quo of white ruling class privilege, attributing to this class all the glory associated with ending the debilitating experience of enslavement. Alberto's poem "12, 13 e 14 de maio" illustrates this dilemma from below, using as sub-plot this overriding politics of abolitionism. "May $12^{\text {th }}$, they flogged us / May $13^{\text {th }}$ they granted us manumission / May $14^{\text {th }}$ they devastated us.". ${ }^{31}$ The poem continues to insist that the granting of freedom was not accompanied by corresponding adjustments in the system of power and labor. The reality of the ex-slave's dependence on the very system he rejected left him few alternatives. "We thought slavery had ended / But at this moment another darkness began". ${ }^{32}$ These lines drive home the everlasting impact of the lack of institutional and social support.

Equally confrontational is Cuti's writing that brings forth the condition of destitution amidst displays of national pride as the country celebrates Independence Day on September $7^{\text {th }}$. The metaphor of a drunken beggar who falls with his hands extended asking for tokens is likened to the May $13^{\text {th }}$ manumission celebration, creating the message of a total disconnect between the reality of impoverished human condition and glorification of nation as it celebrates its achievements. The two co-exist, a tremendous contradiction that does not seem to jar society too much. "Freedom begs next to me / Put on display / Its fascinating belly". ${ }^{33}$ The

\footnotetext{
${ }^{30}$ ALBERTO. "12, 13 e 14 de maio"; CUTI, "O leitor e o texto afro-brasileiro".

31 "12 de maio chicotearam / 13 de maio alforriaram / 14 de maio assolaram." (ALBERTO. 12, 13 e 14 de maio, p. 87, my translation).

32 "Pensávamos ter terminado a escravidão / Mas iniciava neste momento mais uma escuridão." (ALBERTO. 12, 13 e 14 de maio, p. 87, my translation).

33 "A liberdade mendiga junto comigo / Pondo à mostra / Seu fascinante umbigo." (CUTI. Flash crioulo: sobre o sangue e o sonho, p. 24, my translation).
} 
striking image of the beggar's exposed swollen stomach is likened to the image of the slave tied to the whipping post, groaning in pain. They are images of human indignity, manifestations of social ills left unattended.

This open antagonism between the two dates repeats itself in Rodrigues's “Zumbi”. His martyrdom on November $20^{\text {th }} 1695$ pushes forward today sustaining a state of warrior readiness and the conviction that the battle is not over. At the same time, the configuration is less one of physical aggression and more a message of inspirational reinforcement. "November $20^{\text {th }}$ is a warrior song" ${ }^{34}$ Kibuko's "Calendário" and Minka's "Novembro, 20" continue this trend and attribute to November $20^{\text {th }}$ the creation of historical and contemporary pride and dignity. Minka's "Novembro, 20" expresses the value of initiative, the construction of community pride and dignity by celebrating maroonage and martyrdom: "We dismissed the imposed princess / we create a new struggle/ our dignity has a date / heroism developed in the heart of the forest.". ${ }^{35}$ Such verses sensitize about the continuing value of this first hero and the reason for historical re-interpretation in relation to Portuguese power, colonization, and enslavement. They confirm the force of this initial struggle, along with the way it spirals forward into the contemporary sphere, as the community meets the challenges of modern day racisms. The plan of action includes adoption of modern mechanisms to keep the struggle alive. Public spheres, meeting places, publications, and the media all have a role to play in this war: "books filled with Zumbilessons." 36

"Por que o 13 de maio?" 37 is pessimistic in its questioning of what has been achieved. The narrator manifests his indignation and disappointment with those in authority, accusing them of complacency and inaction in the face of dire need. These poets engage in a politics of poetics in which the innovative creative nature of verse is most effective in its manipulations of social realism. Further, writers like Trindade engage poetry as a gateway to their social consciousness. For this persona there is nothing to celebrate. "Sadness: whites, blacks, yellows [Asians] / Face

34 “20 de novembro / é uma canção / guerreira.” (RODRIGUES. Zumbi, p. 25, my translation).

35 "Demitimos a princesa imposta / fazemos a nova luta / dignidade nossa tem data / heroísmo crescido no coração da mata." (MINKA. Novembro, 20, p. 38, my translation). 36 "livros cheios de Zumbilições." (MINKA. Novembro, 20, p. 38, my translation).

${ }^{37}$ TRINDADE. Poesias caderno 5, p. 17. 
inflationary beasts / There are other kinds of captivity [...]" ${ }^{38}$ Past sacrifice meant nothing for they have not eradicated conditions of widespread need that continue to plague everyone. Poetic discourse is aggressive in its demands of unity against racism, hypocrisy and oppression, to break the tragedy, to move past social separations, and strengthen the motherland.

Trindade's poem indicates that a modification has occurred as the historical notion of an enterprise associated with enslavement has been replaced with current contexts in which aesthetic and social arenas attest to community commitment. Poetry does not remain lodged within historical fact of Zumbi's defeat and the destruction of Palmares; poetic value is in the fact of Palmares's edification and in symbolic illustrations of martyrdom, ancestrality, and spiritualization. Quilombo, Palmares, and Zumbi have fundamental ideological roles within contemporary spaces of black movement militancy, in politics, and the Arts. Poetry takes on the challenge of psychological confrontation with pain and suffering, in the expectation of individual capacity to overcome and thrive. This poetic context, while specific to Brazil, has a deeper diasporic intention. Quilombo as interaction and shared legacy makes Palmares an allegory for Brazil, an extension of Africa, and with potential for duplication everywhere as the same space repeating itself for a people whose legacy is connected, complex, and in continuous construction.

Henrique Cunha Jr.'s "Quilombo" and Onawale's "Quilombo" bring the seasoned, almost invisible warrior figure out of the historical settlement into modern urban space. The past legacy haunts the present for this subject still exists, in the dark shadowy images in the big cities of today. Aparecido Tadeu dos Santos's "Olhar para trás" and Miriam Alves" "Noticiário" work the harsh reality of contemporary life through the idea of a community on permanent armed alert, consequences of the current circumstances of hunger, illiteracy, favelas, mud-slides, urban violence, and marginality. In Alves' poem, these are the events that make the six o'clock news and that really seem to lock the community into a defensive mode that is so reminiscent of the historical experience. Poetic tones retain emotional pride even as the images attest to a people under siege. In these verses there is an internal struggle between poetic tones of

\footnotetext{
38 "Tristeza: brancos, pretos e amarelos / Enfrentam as feras inflacionárias / Como uns infelizes polichinelos ... / São outras as formas de cativeiro ..." (TRINDADE. Poesias caderno 5, p. 17, my translation).
} 
pride emanating from identification with the senzala or the quilombo, and the tragic imagery of the daily struggle for survival that is nightmarish in magnitude. "The singing from the slave quarters agitate my dreams / still / The spears of the Quilombos arm my words / still [...] / The floods wash away our shacks / disarm our dreams still."39

Carlos Gabriel continues this thematic trend in "Favelas, quilombos \& senzalas." Alzira Rufino's poem "Brasil Palmares" and Ele Semog's "Nas calçadas da Lapa" are equally compelling. Symbolic struggle emanates from between poetic imagery of beauty and the fact that such imagery is based on stark realistic imagery of tragic proportions. Historic difficulties of enslavement, abuse, and escape project forward to the modern experience of abandonment. In Gabriel's "Favelas, quilombos \& senzalas" urban hostility reinforces the quilombo's poetic relevance as salvation, redemption, and paradise: "It is the sun, the sweat, the anxiety / It is the pain, the hard walk / It is at last peace, so desired / It is love, it is the Quilombo, it is freedom!". ${ }^{40}$ The narrating strategy of allegorical representation continues in Rufino's "Brasil Palmares." The verses seem to combine several events into one while focusing on the expression and mood of the crowd, even on the color of their faces, a mixture and blend of possibilities. The verses capture the general mood of promise and expectation that pushes back against negativisms: lyrical celebration of negritude as identity matches the positive displays of pride and selfassuredness. "Faces with the immensity of the sea / [...] free their name / recently born / like the tree producing flowers / flowers pregnant with fruit / without the smell of the groaning night / in my chest, a movement of strength / and the sun mixing / with the flame of Zumbi", ${ }^{41}$

Writers such as Semog indicate poetically in works such as $A$ cor da demanda that there is an Afro-Brazilian condition that extends outward

39 “O canto da senzala abala meus sonhos / ainda / As lanças dos Quilombos armam minhas palavras / ainda [...] / As inundações desmoronam nossos barracos/ desarmam nossos sonhos ainda." (ALVES. Noticiário, p. 47, my translation).

40 “É o sol, é o suor, é a ansiedade / É a dor, é a dura caminhada / É enfim a paz, tão desejada / É o amor, é o Quilombo, é a liberdade!" (GABRIEL. Favelas, quilombos \& senzalas, p. 25, my translation).

41 “Rostos com a imensidão do mar / [...] libertam seu nome / recém-nascido / como árvore brotando flores / flores grávidas de frutos / sem cheiro de noite gemida / no peito movimento de força / e o sol fazendo a mistura / com a chama de Zumbi." (RUFINO. Eu, mulher negra, resisto, p. 43, my translation). 
to reflect the broader precarious economic circumstances of millions of citizens. Their main sphere of inspiration is life in the big urban centers. Disparaging images work against the view of the urban space as enriching. Semog's "Nas calçadas da Lapa" is striking with its stark imagery of destitution and need, placed alongside spiritual evocations of Zumbi and lamentations of human condition: "There are days that I gaze on / the black folk scattered / Across Lapa's pavements / (Is it I? Is it I?) / drunk, foul-smelling... torn apart... / (woe onto you Zumbi! Woe onto you Zumbi!)." ${ }^{42}$ The psychological effect is devastating for it appears that the subject has lapsed into a state of stupor and ignorance, an animal-like state of nothingness corresponding to blind sensations of surrendering and hopelessness that must have plagued this people during slavery. Their will to resist and fight is overtaken by destitution, drunkenness, and the humiliation of charity. The sidewalk is their place of shame, producing anguished contemplation for the narrator as he makes his way to his black activist meeting. The images are etched in his brain and are intolerable given the inextricable bond between them. The vision of the sidewalk is the inescapable reality of historical failure.

On a different note, Kibuko uses his poems to confirm how modern activism finds inspiration in the successful internal organization and structure of Palmares as a city. Symbols of a complex and organized unity produce poetic optimism and drive the ultimate message of a conviction in the possibility of national transformation. Kibuko's "Em defesa da dignidade" uses building blocks to suggest nation building and the metropolis. "In defense of dignity / a man gave his life / however his act was not in vain / it represents more cement, it represents more bricks / for the QUILOMBO into which we will transform this nation." 43

The common characteristic that binds these writers together is the elaboration of an aesthetic discourse of critical confrontation grounded in values of ancestral fortitude and resistance. This discourse relies on depictions that coincide with the deep sense of social consciousness and

42 "Tem dias que olho / Os negros espalhados / Pelas calçadas da Lapa / (Sou eu? Sou eu?) /bêbados, fétidos... rasgados... / (ai de ti Zumbi! Ai de ti Zumbi!)." (SEMOG. $A$ cor da demanda: poesia afro-brasileira, p. 134, my translation).

43 "Em defesa da dignidade / um homem deu sua vida / porém seu ato não foi em vão / isto é mais cimento, é mais tijolo / pro QUILOMBO em que vamos transformar esta nação.” (KIBUKO. Em defesa da dignidade, p. 105, my translation). 
commitment. Self-defamation alongside self-affirmation work together in this process of poetic construction of Zumbi's peoples and writers are united in their strategy of symbolically representing this legacy of challenges comprising more losses than gains. The Zumbi icon serves this purpose well; it is a vital chain that links potential symbolic glory with realist representation of actual human condition. Zumbi, Palmares, and quilombo must play the multitude of roles needed to illustrate the AfroBrazilian trajectory as the harshness of historical struggle coincides with the beauty of the resistance experience about which poetry recreates. Poetry and reality coincide as the difficulty of sustaining and building Palmares finds duplication in present-day challenges that face black activism in their efforts to keep alive the sense of togetherness and awareness of the epic legacy of which they are a part. The warrior-like spirit of the past is appropriated into poetic writing that in turn complements such action, a means of encouraging militancy today. Zumbi and Palmares were cultivated and brought forward by Abdias do Nascimento and by these Cadernos negros poets and continue to stand at the center of a heritage marked by the need for greater appreciation of these icons.

\section{References}

ALBERTO, José. 12, 13 e 14 de maio. In: CADERNOS Negros. São Paulo: [Author's edition], 1980. v. 3: Poesia, p. 87.

ALVES, Miriam. Noticiário. In: CADERNOS negros. São Paulo: [Author's edition], 1986. v. 9: Poemas, p. 47.

ASSUMPÇÃO, Carlos de. Protesto: poemas. Franca: UNESP, 1988.

BARBOSA, Márcio. A morte. In: CADERNOS negros. São Paulo: [Author's edition], 1986. v. 9: Poemas, p. 56.

BARBOSA, Márcio. Márcio Barbosa. In: CADERNOS negros. São Paulo: [Author's edition], 1985. v. 8: Contos, p.12.

CAMARGO, Oswaldo de. O negro escrito. São Paulo: Secretaria de Estado da Cultura, 1987.

CONCEIÇÃO, Jônatas. No Nordeste existem Palmares. In: BARBOSA, Lindinalva. Quilombo de palavras: a literatura $\overline{\text { dos afro- }}$ descendentes. Salvador: CEAO/UFBA, 2000. p. 25. 
CUNHA JR., Henrique. Quilombo. In: CADERNOS negros. São Paulo: [Author's edition], 1980. v. 3: Poesia, p. 46.

CUTI (Luiz Silva). Flash crioulo: sobre o sangue e o sonho. Belo Horizonte: Mazza, 1987.

CUTI (Luiz Silva). O leitor e o texto afro-brasileiro. In: FIGUEIREDO, Maria do Carmo Lanna; FONSECA, Maria Nazareth Soares. Poéticas afro-brasileiras. Belo Horizonte: PUC Minas, Mazza, 2002. p. 19-36.

DIAS, Gonçalves. Poesia completa e prosa escolhida. Rio de Janeiro: José Aguilar, 1959.

FUNARI, Pedro Paulo A. Conflict and the Interpretation of Palmares, a Brazilian Run-Away Polity. Historical Archeology, Germantown, MD, v. 37, n. 3, p. 81-92, 2003. Available at: <http://www.jstor.org/ stable/25617082>. Accessed on: 2 Feb. 2013.

GABRIEL, Carlos. Favelas, quilombos \& senzalas. In: CADERNOS negros. São Paulo: Quilombhoje, Anita, 1998. v. 21: Poemas afrobrasileiros, p. 24-27.

KIBUKO, Oubi Inae. Calendário. In: CADERNOS negros. São Paulo: Quilombhoje, 1994.v. 17: p. 62.

KIBUKO, Oubi Inae. Em defesa da dignidade. In: CADERNOS negros. São Paulo: [Author's edition], 1984. v. 7: Poemas, p. 104-105.

KIBUKO, Oubi Inae. Reflexão sobre literatura negra na realidade política brasileira. In: ALVES, Miriam; CUTI (Luiz Silva); XAVIER, Arnaldo (Org.). Criação crioula nu elefante branco. São Paulo: IMESP, 1986. p. 135-140.

LEITE, José Correia; CUTI (Luis Silva)....E disse o velho militante José Correia Leite. São Paulo: Secretaria Municipal de Cultura, 1992.

LIMEIRA, José Carlos. Zumbi. In: CADERNOS negros. São Paulo: [Author's edition], 1980. v. 3: Poesia, p. 107.

MARTINS, Sérgio da Silva et.al. Paving Paradise: The Road from "Racial Democracy" to Affirmative Action in Brazil. Journal of Black Studies, Philadelphia, PA, v. 34, n. 6, p. 787-816, jul. 2004. Available at: <http:// www.jstor.org/stable/3180914>. Access on: 4 Mar. 2013.

MINKA, Jamu. Dos Palmares. In: CADERNOS negros. São Paulo: [Author's edition], 1980. v. 3: Poesia, p.85. 
MINKA, Jamu. Novembro, 20. In: CADERNOS negros. São Paulo: Quilombhoje, 1994. v. 17: p. 38.

NASCIMENTO, Abdias do. Abdias do Nascimento. In: UCHÔA, Pedro Celso; RAMOS, Jovelino (Org.). Memórias do Exílio: Brasil 1964-19??. Lisboa: Arcádia, 1976. p. 23-52.

NASCIMENTO, Abdias do. African Culture in Brazilian Art. Journal of Black Studies, Philadelphia, v. 8, n. 4, p. 389-422, jun. 1978. Available at: $<$ https://www.jstor.org/stable/2783882?seq=1\#metadata_info_tab_ contents $>$. Accessed on: 3 Sept. 2013.

NASCIMENTO, Abdias do. Brazil: Mixture or Massacre? Essays in the Genocide of a Black People. 2. ed. Trans. Elisa Larkin Nascimento. Dover, MA: The Majority Press, 1989.

NASCIMENTO, Abdias do. O Quilombismo. Petrópolis: Vozes, 1980.

NASCIMENTO, Abdias do. Sortilégio II: mistério negro do Zumbi redivivo. Rio de Janeiro: Paz e Terra. 1979.

NASCIMENTO, Abdias do. Sortilégio: mistério negro. Rio de Janeiro: Teatro Experimental do Negro, 1959.

NASCIMENTO, Abdias do; NASCIMENTO, Elisa Larkin. Africans in Brazil: A Pan-African Perspective. Trenton, NJ: African World Press, 1992.

NASCIMENTO, Elisa Larkin. A questão de gênero na peça Sortilégio (Mistério Negro) de Abdias Nascimento. União do Escritores Angolanos, [S.1.], [20--]. Available at: $<$ http://www.ueangola.com/criticas-e-ensaios/ item $/ 225$-a-quest $\% \mathrm{C} 3 \% \mathrm{~A} 30-d e-g \% \mathrm{C} 3 \%$ AAnero-na-pe $\% \mathrm{C3} \% \mathrm{~A} 7 \mathrm{a}-$ sortil\%C3\%A9gio-mist\%C3\%A9rio-negro-de-abdias-nascimento>. Accessed on: 1 Oct. 2013.

OJO-ADE, Femi. Being Black, Being Human: More Essays on Black Culture. Trenton, NJ; Asmara, Eritrea: Africa World Press, 2004.

OJO-ADE, Femi. Black Brazil: African Notes on a New Negritude. In: CROOK, Larry; JOHNSON, Randal (Ed.). Black Brazil: Culture, Identity, and Social Mobilization. Los Angeles: UCLA Latin American Studies, 1999. p. 175-197.

ONAWALE, Landê. Quilombo. In: CADERNOS negros. São Paulo: Quilombhoje, Anita, 1998. v. 21: Poemas afro-brasileiros, p. 84. 
RATTS, Alessandro José Prudencio. A voz que vem do interior: intelectualidade negra e quilombo. In: BARBOSA, Lúcia Maria de Assunção et. al. (Org.). Do preto a afro-descendente: Trajetos de Pesquisa sobre o negro, cultura negra e relações étnico-raciais no Brasil. São Carlos: EdUFSCar, 2003. p. 89-108.

RIBEIRO, Esmeralda. Africa-Brasil. In: CADERNOS negros. São Paulo: Quilombhoje, 2002. v. 25: Poemas afro-brasileiros, p. 80-82.

RODRIGUES, Abelardo. À Procura de Palmares. In: CADERNOS negros. São Paulo: [Author's edition], 1980. v. 3: Poesia, p. 13.

RODRIGUES, Abelardo. Zumbi. In: CADERNOS negros: os melhores poemas. São Paulo: Quilombhoje, 1998. p. 25.

RUFINO, Alzira. Eu, mulher negra, resisto. Santos: [Author's edition], 1988.

SANTANA, Everaldo Lins de. Breve reflexão sobre a Lei 10.639. MultiSaberes, [s.l.], v. 1, n. 1, p. 1-7, mar, 2011.

SANTOS, Aparecido Tadeu dos. Olhar para trás. In: CADERNOS negros. São Paulo: [Author's edition], 1980. v. 3: Poesia, p. 29.

SANTOS, João Felício dos. Ganga-Zumba. Rio de Janeiro: Civilização Brasileira, 1962.

SEMOG, Ele. A cor da demanda: poesia afro-brasileira. Rio de Janeiro: Letra Capital, 1997.

TEODORO, Aristides. Queria ser um deus. In: CADERNOS negros. São Paulo: [Author's edition], 1980. v. 3: Poesia, p. 31.

TRINDADE, Solano. Poesias caderno 5. Vitória: CECUN, 1985.

VENTURA, Adão. A cor da pele. Belo Horizonte: [Author's edition]. 1981.

Recebido em: 19 de junho de 2018. Aprovado em: 20 de novembro de 2018. 